\title{
Quality Evaluation of Pasta Fortified With Roasted Sesame Flour
}

\author{
* O.H. Animashaun, O.O. Olorode, K.S. Sofunde, M.A. Idowu \\ (Department of Food Technology, Moshood Abiola Polytechnic, Nigeria) \\ Corresponding Author: O.H. Animashaun
}

\begin{abstract}
Pasta is a stable food product that is eaten by both young and old in many parts of the world. The quality characteristics of pasta fortified with roasted sesame flour were evaluated. Sesame seeds were processed into flour after roasting and incorporated into wheat flour in ratio of 100:0, 90:10, 80:20, 70:30, 60:40 and 50:50 (wheat: roasted sesame flour). The functional, proximate and mineral composition of flour blends and sensory attribute of spaghetti produced from the blends were carried out according to standard methods. The result of functional properties revealed that values for flour blend with $50 \%$ sesame flour had the highest value for water absorption capacity, solubility and gelatin and least value for bulk density BD and swelling capacity. The result of proximate composition showed that values for protein, fat, fibre, ash, moisture and carbohydrate ranged from 6.78 to $15.16 \%, 1.05$ to $1.33 \%, 0.23$ to $0.68 \%, 1.29$ to $1.98 \%, 10.50$ to $13.11 \%$ and 70.27 to 76.50 respectively. From the result obtained, it can be concluded that acceptable spaghetti with high nutritional and sensory attributes can be produced from the blends of wheat-sesame at $20 \%$ inclusion level, which can help in solving the lingering problem of protein malnutrition.
\end{abstract}

Keywords: Pasta, Sesame seed, Wheat, Functional properties, Proximate composition.

Date of Submission: 12-04-2017

Date of acceptance: 15-07-2017

\section{Introduction}

Legumes are staple food for many people in different parts of the world. The seeds have an average of twice as much protein as cereals by percentage and usually contain more balanced profile of essential amino acids[1]. Numerous varieties of oil crops occur ranging from commonly known and utilized ones such as groundnut, soy bean, palm kernel, cotton seed, olive and safflower to underutilized ones such as walnut, locust bean, African oil bean and sesame seed[2]. Sesame seed (Sesamumindicum L.) also known as benniseeds, belongs to the family Pedaliacea. The seeds are mucilaginous in nature and are among the most ancient oil seeds crop known to mankind. Beniseed flour can be used in food products as a protein, tryptophan, methionine and cyesteine[3], these amino acids are missing from other oil seeds. It is also an excellent source of high quality oil (very stable and free-flavour component, with natural anti-oxidant which prevents ageing) and vital for production of liver cells[4]. It has also been valued as a healthy food addictive, preventing disease and promoting well-being. It is also use as cancer prevention, prevention of heart disease, and antioxidant, hepatoprotective (Lecothin)[5]. Sesame seed consumption increases plasma gama-tocopherol and enhance vitamin E activity, which is believed to prevent cancer and heart disease[6]. The local names of sesame seed in Nigeria include 'eleru' and 'ekuku' (Yoruba) and 'gorigo' (Ebiras). They are used as a soap condiment in some Northern Nigerian states and few parts of Cross-river state[7].

Pasta is a source of carbohydrates (74-77\%, dry basis) whose interest is increasing due to nutritional properties, particularly its low glycemic index (GI)[8]. Pasta also contain 11-15\% (db) proteins but is deficient in lysine and threonine (the first and second limiting amino acid), common to most cereal products [9]. It is a stable food product that is produced mainly by mixing durum wheat semolina and water[10]. Pasta has become recognized as a healthy food, with a low fat content, no cholesterol and a low glycemic index[11]. Gluten, gotten from wheat is considered to be one most significant factor related to pasta cooking quality[12], because it contains gladin and glutenin which are responsible for its elascity and chewability, this in turn makes wheat flour inevitable in pasta production. Makinde and Akinoso[2], reported that application of processes such as roasting and fermentation will contribute to increased production and utilization of the crop for enhanced food and nutrition security in Nigeria and other developing countries. Wheat apart from being a good source of calories and other nutrients is considered nutritionally poor, as cereals protein are deficient in essential amino acids such as lysine and threonine. Over reliance on wheat flour in many countries has led to little consideration for locally grown crops, which could be used as partial or total replacement of wheat. The present exchange rate has contributed immensely to increase in the cost of wheat flour, making its product relatively scarce and expensive. Sesame seed with its inherent nutritional composition will enhance the quality of the spaghetti, by increasing the level of essential amino acids. This will improve the utilization of locally grown crops, by 
reducing dependency on wheat and also solving the problem of protein malnutrition. This work therefore aimed at evaluating the quality characteristics of pasta fortified with roasted sesame flour.

2.1 Source of Materials

\section{Materials and methods}

sesame seed and wheat flour were purchased from Lafenwa market in Abeokuta, Ogun state, Nigeria

\subsection{Methodology}

\subsubsection{Processing of Roasted Sesame Seed Flour}

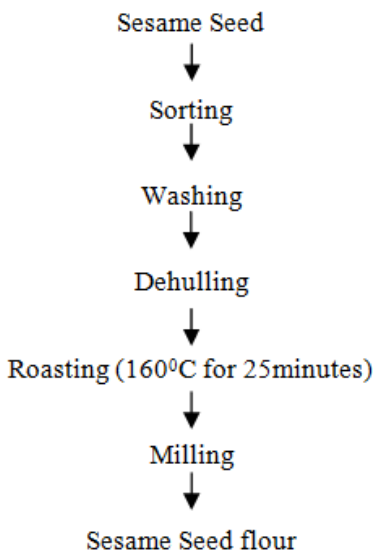

Fig 1: Flow chart for the production of roasted sesame seed flour

Source: Makinde and Akinoso[2]

\subsubsection{Formulation of composite flour}

Wheat and roasted sesame flours were mixed at different proportions of 100:0, 90:10, 80:20, 70:30, 60:40 and 50:50 respectively.

\subsubsection{Spaghetti Processing}

The formulated composite blends were used for spaghetti processing. The homogenized blend was mixed with water $(50 \mathrm{ml}$ of water for $100 \mathrm{~g}$ of flour) for $5 \mathrm{~min}$ to allow hydration. The dough was obtained, and extruded as spaghetti (3-mm diameter) using a locally fabricated extruder at the processing workshop of the Department of Food Technology, Moshood Abiola Polytechnic. The barrel temperature was $45^{\circ} \mathrm{C}$ and the screw speed was at $6 \mathrm{rpm}$. The spaghettis were cut as they came out of the pasta roller and dried at $45^{\circ} \mathrm{C}$ for 7 hours.

\subsection{Analysis}

\subsubsection{Functional properties}

The bulk density, water and oil absorption capacity of each of the sample was determined according to the method of Giami et al.[13]. Gelation Capacity was determined according to the method described by Onwuka[14]. Swelling power and solubility profile of the starch samples were determined according to the method described by Adebowale et al.[15].

\subsubsection{Proximate Composition}

Moisture, ash, protein content determination was carried out using the method of AOAC[16]. The carbohydrate content was calculated by difference using the method described by Rampersad et al.[17].

\subsubsection{Determination of Mineral Content}

The magnesium content of the samples was determined by the EDTA complexometric titration methods[18] while the Iron, Zinc and calcium contents were determined according to the method described by AOAC and Ochai and kolhatkan[19,20].

\subsubsection{Sensory Analysis}

Pasta was evaluated for appearance, chewiness, glossiness, crunchiness, taste, firmness and overall acceptability using 9-point hedonic scale with the help of twenty (20) semi-trained panelists drawn within the Polytechnic community.

\subsection{Statistical Analysis}

The data obtained were subjected to Analysis of variance (ANOVA) using statistical package. Means were separated using Duncan multiple test (DMRT). The least significance difference (LSD). Significance was accepted at $(\mathrm{P} \leq 0.05)$ 


\section{Result}

The result for proximate composition of flours from wheat-sesame blends is presented in Table 1. The value for Moisture, fat, ash, protein, crude fibre and carbohydrate contents ranged from 10.50-13.11\%, 1.05$1.33 \%, 1.29-1.98 \%, 6.78-15.16 \%, 0.23-0.68 \%$ and $70.27-76.510 \%$ respectively. The water absorption, oil absorption, bulk density, swelling capacity, solubility and gelation temperature values ranged from 1.72$1.91 \mathrm{~g} / 100 \mathrm{~g}, 1.27-1.76 \mathrm{~g} / 100 \mathrm{~g}, 0.74-0.95 \mathrm{~g} / \mathrm{ml}, 3.45-5.80 \mathrm{~g} / \mathrm{g}, 0.06-0.39 \%, 65.50-79.40^{0} \mathrm{C}$ respectively (Table 2). The calcium, zinc, magnesium and Iron values ranged from $36108.46-54821.60 \mathrm{mg} / \mathrm{kg}, 63.65-87.56 \mathrm{mg} / \mathrm{kg}$, $2689.55-3726.23 \mathrm{mg} / \mathrm{kg}$ and $250.5-373.00 \mathrm{mg} / \mathrm{kg}$ respectively (Table 3). While Table 4 shows the Sensory evaluation of spaghetti from wheat-sesame flour blends with values ranging from 3.95-7.90, 3.95-7.35, 4.157.70, 4.05-7.65, 3.95-7.50 and 4.05-7.50 for appearance, chewiness, glossiness, taste, firmness and overall acceptability respectively

TABLE 1: Proximate Composition of Wheat- Sesame Flour Blends

\begin{tabular}{|c|c|c|c|c|c|c|}
\hline PARAMETERRS & Moisture (\%) & $\begin{array}{l}\text { Fat } \\
(\%) \\
\end{array}$ & $\begin{array}{l}\text { Ash } \\
(\%) \\
\end{array}$ & $\begin{array}{l}\text { C. Fibre } \\
(\%)\end{array}$ & C. Protein (\%) & $\begin{array}{l}\text { CHO } \\
(\%) \\
\end{array}$ \\
\hline 100\%WF:0\%SF & $13.03^{\mathrm{a}} \pm 0.06$ & $1.05^{\mathrm{c}} \pm 0.06$ & $1.98^{\mathrm{a}} \pm 0.05$ & $0.66^{\mathrm{a}} \pm 0.50$ & $6.78^{\mathrm{f}} \pm 0.03$ & $76.50^{\mathrm{a}} \pm 0.07$ \\
\hline $90 \% W F: 10 \%$ SF & $13.11^{\mathrm{a}} \pm 0.13$ & $1.14^{\mathrm{bc}} \pm 0.04$ & $1.92^{\mathrm{a}} \pm 0.99$ & $0.68^{\mathrm{a}} \pm 0.50$ & $11.12^{\mathrm{e}} \pm 0.04$ & $72.03^{\mathrm{b}} \pm 0.09$ \\
\hline $80 \% W F: 20 \%$ SF & $13.08^{\mathrm{a}} \pm 0.64$ & $1.13^{\mathrm{bc}} \pm 0.08$ & $1.71^{\mathrm{b}} \pm 0.08$ & $0.61^{\mathrm{ab}} \pm 0.11$ & $11.96^{\mathrm{d}} \pm 0.13$ & $71.51^{\mathrm{c}} \pm 0.04$ \\
\hline $70 \% W F: 30 \%$ SF & $13.04^{\mathrm{a}} \pm 0.71$ & $1.25^{\mathrm{ab}} \pm 0.01$ & $1.72^{\mathrm{b}} \pm 0.02$ & $0.48^{\mathrm{b}} \pm 0.05$ & $13.03^{\mathrm{c}} \pm 0.07$ & $70.48^{\mathrm{d}} \pm 0.06$ \\
\hline $60 \% W F: 40 \%$ SF & $12.69^{\mathrm{b}} \pm 0.01$ & $1.28^{\mathrm{ab}} \pm 0.03$ & $1.34^{\mathrm{c}} \pm 0.01$ & $0.52^{\mathrm{ab}} \pm 0.06$ & $13.90^{\mathrm{b}} \pm 0.18$ & $70.27^{\mathrm{d}} \pm 0.21$ \\
\hline $50 \% W F: 50 \%$ SF & $10.50^{c} \pm 0.08$ & $1.33^{\mathrm{a}} \pm \mathbf{0 . 1 3}$ & $1.29^{\mathrm{c}} \pm 0.02$ & $0.23^{\mathrm{c}} \pm 0.33$ & $15.16^{\mathrm{a}} \pm 0.27$ & $71.49^{c} \pm 0.01$ \\
\hline
\end{tabular}

Values with different letter superscripts in the same column are different significantly from each other $(\mathrm{P}<0.05)$. WF - Wheat flour, SF - Sesame flour, C- Crude, CHO - Carbohydrate

TABLE 2: Functional Properties of Wheat-Sesame Flour Blends

\begin{tabular}{|c|c|c|c|c|c|c|}
\hline PARAMETERRS & WAC (g/100g) & OAC (g/100g) & $\begin{array}{l}\text { Bulk. D } \\
\text { (g/100g) }\end{array}$ & $\begin{array}{l}\text { Swelling } \\
\text { C. }(g / g)\end{array}$ & $\begin{array}{l}\text { Solubility } \\
\text { (g/ml) }\end{array}$ & $\begin{array}{l}\text { Gelation } \\
\left({ }^{0} \mathrm{C}\right)\end{array}$ \\
\hline 100\%WF:0\%SF & $1.72^{\mathrm{d}} \pm 0.00$ & $1.68^{\mathrm{b}} \pm 0.00$ & $0.95^{\mathrm{a}} \pm 0.00$ & $5.40^{\mathrm{b}} \pm 0.00$ & $0.06^{\mathrm{b}} \pm 0.00$ & $65.50^{\mathrm{d}} \pm 0.14$ \\
\hline $90 \% W F: 10 \%$ SF & $1.77^{\mathrm{b}} \pm 0.00$ & $1.27^{\mathrm{c}} \pm 0.00$ & $0.91^{\mathrm{b}} \pm 0.00$ & $5.80^{\mathrm{a}} \pm 0.00$ & $0.06^{\mathrm{b}} \pm 0.00$ & $65.55^{\mathrm{d}} \pm 0.07$ \\
\hline 80\%WF:20\%SF & $1.73^{\mathrm{d}} \pm 0.00$ & $1.76^{\mathrm{a}} \pm 0.00$ & $0.87^{\mathrm{c}} \pm 0.00$ & $4.73^{\mathrm{c}} \pm 0.00$ & $0.06^{\mathrm{b}} \pm 0.00$ & $65.55^{\mathrm{d}} \pm 0.07$ \\
\hline $70 \% W F: 30 \%$ SF & $1.74^{\mathrm{c}} \pm 0.00$ & $1.68^{\mathrm{b}} \pm 0.00$ & $0.83^{\mathrm{d}} \pm 0.00$ & $3.91^{\mathrm{d}} \pm 0.00$ & $0.06^{\mathrm{b}} \pm 0.00$ & $75.55^{\mathrm{c}} \pm 0.07$ \\
\hline $60 \% W F: 40 \%$ SF & $1.72^{\mathrm{d}} \pm 0.00$ & $1.71^{\mathrm{b}} \pm 0.03$ & $0.80^{\mathrm{e}} \pm 0.00$ & $3.80^{\mathrm{e}} \pm 0.00$ & $0.07^{\mathrm{b}} \pm 0.00$ & $76.20^{\mathrm{b}} \pm 0.00$ \\
\hline 50\%WF:50\%SF & $1.91^{\mathrm{a}} \pm 0.00$ & $1.67^{\mathrm{b}} \pm 0.00$ & $0.74^{\mathrm{f}} \pm 0.00$ & $3.45^{\mathrm{f}} \pm 0.00$ & $0.39^{\mathrm{a}} \pm 0.00$ & $79.40^{\mathrm{a}} \pm 0.14$ \\
\hline
\end{tabular}

Values with different letter superscripts in the same column are different significantly from each other $(\mathrm{P}<0.05)$. $\mathrm{WAC}=$ Water Absorption Capacity, OAC $=$ Oil Absorption Capacity, Bulk. D = Bulk Density WF - Wheat flour, SF - Sesame flour

TABLE 3: Mineral Analysis of Wheat- Sesame Flour Blends

\begin{tabular}{|c|c|c|c|c|}
\hline SAMPLES & $\mathrm{Ca}(\mathrm{mg} / \mathrm{Kg})$ & Zn (mg/Kg) & Mg (mg/Kg) & Fe (mg/Kg) \\
\hline 100\%WF:0\%SF & $5482160^{\mathrm{a}} \pm 0.00$ & $63.65^{\mathrm{d}} \pm 0.50$ & $3726.23^{\mathrm{a}} \pm 3.64$ & $278.29^{c} \pm 0.98$ \\
\hline 90\%WF:10\%SF & $46279.56^{\mathrm{b}} \pm 4106.26$ & $85.97^{\mathrm{a}} \pm 0.66$ & $3164.22^{\mathrm{c}} \pm 1.73$ & $373.00^{\mathrm{a}} \pm 8.36$ \\
\hline $80 \% W F: 20 \%$ SF & $40026.3^{c} \pm 130.38$ & $85.97^{\mathrm{a}} \pm 0.66$ & $2731.01^{\mathrm{d}} \pm 45.93$ & $373.00^{\mathrm{a}} \pm 8.36$ \\
\hline $70 \% W F: 30 \% \mathrm{SF}$ & $38806.60^{\mathrm{c}} \pm 665.55$ & $73.65^{\mathrm{c}} \pm 0.50$ & $2689.55^{\mathrm{d}} \pm 45.93$ & $327.07^{\mathrm{b}} \pm 4.33$ \\
\hline $60 \% W F: 40 \% \mathrm{SF}$ & $36321.33^{c} \pm 1795.65$ & $87.56^{\mathrm{a}} \pm 0.78$ & $3271.46^{\mathrm{bc}} 126.06$ & $250.51^{\mathrm{d}} \pm 7.64$ \\
\hline 50\%WF:50\%SF & $36108.46^{c} \pm 295.08$ & $77.56^{\mathrm{b}} \pm 0.78$ & $3313.66^{\mathrm{b}} \pm 2.35$ & $273.99^{c} \pm 7.06$ \\
\hline
\end{tabular}

Values with different letter superscripts in the same column are different significantly from each other $(\mathrm{P}<0.05)$. $\mathrm{Ca}=$ Calcium, $\mathrm{Zn}=\mathrm{Zinc}, \mathrm{Mg}=$ Magnesium and $\mathrm{Fe}=$ Iron

WF - Wheat flour, SF - Sesame flour

TABLE 4: Sensory Evaluation of Spaghetti from wheat-Sesame Flour Blends

\begin{tabular}{lllllll}
\hline Parameters & $100 \mathrm{WF}$ & $90 \% \mathrm{WF}: 10 \% \mathrm{SF}$ & $80 \% \mathrm{WF}: 20 \%$ SF & $70 \% \mathrm{WF}: 30 \% \mathrm{SF}$ & $60 \% \mathrm{WF}: 40 \% \mathrm{SF}$ & $50 \% \mathrm{WF}: 50 \% \mathrm{SF}$ \\
\hline Appearance & $7.90^{\mathrm{a}} \pm 0.64$ & $6.00^{\mathrm{c}} \pm 0.97$ & $6.80^{\mathrm{b}} \pm 1.12$ & $5.65^{\mathrm{c}} \pm 0.93$ & $4.40^{\mathrm{d}} \pm 0.94$ & $3.95^{\mathrm{d}} \pm 1.57$ \\
Chewiness & $7.35^{\mathrm{a}} \pm 0.93$ & $6.40^{\mathrm{b}} \pm 1.27$ & $6.65^{\mathrm{ab}} \pm 1.09$ & $5.35^{\mathrm{c}} \pm 1.42$ & $4.20^{\mathrm{d}} \pm 1.32$ & $3.95^{\mathrm{d}} \pm 1.28$ \\
Glossiness & $7.70^{\mathrm{a}} \pm 0.66$ & $5.85^{\mathrm{c}} \pm 1.46$ & $6.95^{\mathrm{b}} \pm 1.10$ & $5.45^{\mathrm{c}} \pm 0.61$ & $4.45^{\mathrm{d} \pm 1.47}$ & $4.15^{\mathrm{d}} \pm 1.31$ \\
Taste & $7.65^{\mathrm{a}} \pm 0.93$ & $6.35^{\mathrm{b}} \pm 0.93$ & $7.05^{\mathrm{a}} \pm 1.15$ & $5.35^{\mathrm{c}} \pm 1.04$ & $4.05^{\mathrm{d}} \pm 1.15$ & $4.10^{\mathrm{d}} \pm 0.85$ \\
Firmness & $7.50^{\mathrm{a}} \pm 0.76$ & $6.20^{\mathrm{b}} \pm 0.95$ & $6.85^{\mathrm{ab}} \pm 0.88$ & $5.35^{\mathrm{c}} \pm 0.99$ & $4.55^{\mathrm{d}} \pm 1.40$ & $3.95^{\mathrm{d}} \pm 1.32$ \\
Overall. A & $7.50^{\mathrm{a}} \pm 0.70$ & $6.30^{\mathrm{b}} \pm 1.08$ & $6.75^{\mathrm{b}} \pm 0.78$ & $5.35^{\mathrm{c}} \pm 1.35$ & $4.20^{\mathrm{d}} \pm 1.20$ & $4.05^{\mathrm{d}} \pm 1.4$ \\
\hline
\end{tabular}

Values with different letter superscripts in the same column are different significantly from each other $(\mathrm{P}<0.05)$. WF - Wheat flour, SF - Sesame flour

\section{Discussion}

Moisture content is the amount of water in a material or substance. Different food materials have different capacity for absorbing and retaining moisture. As sesame flour was added to wheat flour, it tends to bind moisture content of the composite flour samples. The decrease in moisture content with increase in level of substitution showed the certainty of prolonging shelf life. The fat content of the flour was observed to increase 
with increased level of roasted sesame flour addition as roasted sesame flour is indeed rich in fat. Fagbemi and Oshodi[21] states that fat provides energy and is essential as it carries along fat soluble vitamin A, D, E and K. Relatively, high fat could be undesirable because fat can promote rancidity in foods, leading to development of unpleasant and odorous compounds[22]. The ash content of the flour samples ranged from 1.29-1.98\%. The flour sample from $100 \%$ Wheat had the highest value while sample produced from $50 \%$ Sesame had the least value. The ash content was found to reduce with increased substitution of sesame flour. There was no significant difference $(\mathrm{P}>0.05)$ among the samples. This work is line with the work of Oladunmoye et al.[23] who recorded lesser ash content. This may be due to the differences in the composition of durum wheat semolina and wheat flour. For crude fibre, $50 \%$ SF produced the lowest value with $0.23 \%$, while $10 \%$ SF had the highest with $0.68 \%$. The crude fibre was much lower as against that of wheat-walnut flours as reported by Offia-Olua[24]. Fibre is important for the removal of waste from the body thereby preventing constipation and many health disorders. The viscose and fibrous structure of dietary fibre controls the release of glucose with time in the blood, which helps in proper control and management of diabetes mellitus and obesity[25,26]. The protein contents of the flour samples were significantly different $(\mathrm{P}<0.05)$ from each other. The protein content ranged from 6.78 to $15.16 \%$, where $50 \% \mathrm{SF}$ had the highest value. Increase in protein content was observed with increased substitution level of roasted sesame flour. This could be attributed to high percentage of protein content in roasted sesame flour which agreed with the work of Makinde and Akinoso[2]. The carbohydrate content ranged from 70.27 to $76.50 \%$. There was a corresponding decrease in carbohydrate content as sesame flour was added, except for $50 \% \mathrm{SF}$ which was higher than 30 and $40 \% \mathrm{SF}$. This was in contrast with the work of Offia-olua[24] which showed significant decrease in carbohydrate value as walnut was added to wheat flour.

The result of functional properties of flours from roasted sesame and wheat blends is shown in Table 2. For Water absorption, sample with 50\%WF:50\%SF had the highest score (1.91), while the least score was sample with $100 \%$ WF (1.72). Water absorption capacity (WAC) is the ability of flour to absorb water and swell for improved consistency in food, it is desirable in food systems to improve yield and consistency and give body to the food[27]. The high WAC observed in the flour samples could be due to the high protein content of the flour due to addition of processed sesame seed flour, which has high affinity for water molecules[28]. It has been suggested that flours with such high water absorption capacity as seen in this study will be very useful in bakery products, as this could prevent staling by reducing moisture loss. The Bulk density was found to range from 0.74 to $0.95 \mathrm{~g} / 100 \mathrm{~g}$, the samples were significantly different $(\mathrm{P}<0.05)$ from one another. The bulk density was found to decrease with increase in the level of substitution. The change in bulk density is generally affected by the particle size and the density of the flour, it is very important in determining packaging requirement and material handling[29]. Although high bulk density is important due to the packaging advantage it offers flour products[30], low bulk density could be an advantage in foods where high nutrient density to low bulk is desired. This is because the lower the bulk density value, the higher the amount of flour particles that can stay together and thus increasing the energy content that could be derivable from such diets[31]. The Swelling capacity of the flours ranged from 3.45 to $5.80 \mathrm{~g} / \mathrm{g}$. There was significant difference $(\mathrm{P}<0.05)$ between the samples. Decrease in swelling capacity was observed with increase in substitution level, except for sample with $100 \%$ WF. Moorthy and Ramanujam[32], reported that the swelling capacity of flour granules is an indicator of the extent of associative forces within the granule. This also explains the amount of water needed to change a given amount of flour from its powered form to its viscoelastic form[33]. Swelling and water absorption capacities are important parameters which ultimately determine sample consistency (that is solid, semi-solid, or liquid) and are dependent on the compositional structure of the sample[34,35]. The Oil absorption capacity of the flours ranged from 1.27 to $1.76 \mathrm{~g} / 100 \mathrm{~g}$, with sample $10 \% \mathrm{SF}$ having the lowest and $80 \mathrm{WF}: 20 \%$ SF having the highest value. Oil absorption capacity is attributed mainly to the physical entrapment of oils, it is an indicator of the rate at which the protein binds to fat in food formulation[36]. In terms of Solubility, values ranged from 0.06 to $0.39 \%$. The increase in the solubility of the flour blends might be due to increase in the protein content of the flour blends. Solubility is an index of protein functionality such as denaturation and its potential applications[37]. This is however in agreement with the work of Omueti et al.[37] titled "Solubility of complementary diets developed from soybean, groundnut and crayfish". For Gelation capacity, which is the lowest protein concentration at which gel remains in the inverted tube, the range was from $65.50^{\circ} \mathrm{C}$ to $79.40^{\circ} \mathrm{C}$.. It was observed that Gelation temperature increased with increase in substitution level of roasted sesame flour. The increase in the Least gelation concentration (LGC) of the flour samples might be due to break down of starch into high amount of amylose and amylopectin molecules (enzymic breakdown of carbohydrates) as well as protein hydrolysis during various processing methods employed[38].

The result of mineral composition of the flour from roasted sesame flour and wheat is shown in Table 3. For Calcium, the highest score was sample with $100 \%$ WF having $54821.60 \mathrm{mg} / \mathrm{kg}$, while the least was $50 \% \mathrm{SF}$ with $36108.46 \mathrm{mg} / \mathrm{kg}$. Sample $100 \%$ was significantly different $([\mathrm{P}<0.05)$ from other samples, while sample $20 \% \mathrm{~S}, 30 \%, 40 \% \mathrm{~F}$ and $50 \% \mathrm{~F}$ were not significantly different $(\mathrm{P}>0.05)$ from each other. There was decrease in the level of calcium with the addition of sesame flour. Weaver and Heaney[39] reported that calcium is a 
micronutrient essential to health and wellbeing, which performs diverse biological function in the human body. It serves as a second messenger for nearly every biological process, stabilizes many protein and in deficient amounts is associated with a large number of disease. The Food and Nutrition Board[40] recommended a dietary allowance of $360 \mathrm{mg}$ and $1200 \mathrm{mg}$ calcium for infants and young adults. A deficiency in calcium could lead to ricket or osteoporosis. For Zinc, the score ranged from 63.65 to $87.56 \mathrm{mg} / \mathrm{kg}$. The highest were $10 \% \mathrm{SF}$ and $20 \%$ SF, while the lowest was $100 \% \mathrm{WF}$. Zinc positively influences tissue growth and healing and participates in insulin formation and spermatogenesis. Zinc deficiency causes growth retardation, impaired immune functions, loss of appetite and skin, nail and hair change (white spots on nails), acrodermatites enteropathica (hair loss, diarrhoea, anorexia)[41]. The values obtained for zinc are more than the recommended daily allowance of $15 \mathrm{mg}$ and maximum allowable intake of $11 \mathrm{mg}$. For Magnesium, the score ranged from 2689.55 to $3726.23 \mathrm{mg} / \mathrm{kg}$. The sample with the highest was $100 \% \mathrm{WF}$, it was significantly difference $(\mathrm{P}<0.05)$ from other samples but there was no significant difference $(\mathrm{P}>0.05)$ between other samples. Magnesium is essential for all biosynthetic processes including glycolysis, formation of cyclic AMP, energy dependent membrane transport and transmission of the genetic code. Greater than 300 enzymes are known to be activated by magnesium ion[39]. For Iron, the score was between 250.51 and 373.00 . The lowest was $40 \%$ SF, while the highest were $10 \%$ SF and $20 \%$ SF. The samples with the highest score were significantly different $(\mathrm{P}>0.05)$ from other samples. The sample with the lowest score was not significantly different $(\mathrm{P}<0.05)$ from sample with 50\%SF. Iron has several functions in the human body which includes; being a constituent of the haemoglobin molecule - 70\%, myoglobin stored in muscles, an activating molecule of several enzymes and found in storage molecules such as ferritin and hemosiderin. Iron deficiency anemia - characterized by small red cells (microcytosis) with low haemoglobin (hypochromia). The values obtained in this study are more than the recommended daily allowance of $18 \mathrm{mg}$ reported by Ikpeme-Emmanuel et al.[41].

The sensory attributes of Spaghetti from wheat-sesame flour blends is shown in Table 4. The mean score for appearance ranged from 3.95 to 7.90. Spaghetti sample produced from 100\%WF had the highest mean score (7.90) closely followed by sample produced with $10 \%$ and $20 \% \mathrm{SF}$ with mean scores of 6.00 and 6.80 respectively. The chewiness and glossiness of the spaghetti ranged from 3.95 to 7.35 and 4.15 to 7.70 respectively. For chewiness, there was no significant difference $(\mathrm{P}>0.05)$ between the $100 \% \mathrm{WF}$ and every other samples except $20 \%$ SF, while for glossiness, $100 \%$ WF which had the highest score (7.70) was significantly different $(\mathrm{P}<0.05)$ from other samples, where $10 \% \mathrm{~S}$ and $30 \% \mathrm{SF}, 40 \% \mathrm{SF}$ and $50 \% \mathrm{SF}$ were not significantly different from each other. In terms of taste, $100 \%$ WF had the highest value closely followed by $80 \%$ WF with values of 7.65 and 7.05 respectively. For firmness, there was no significant difference $(\mathrm{P}>0.05)$ from $100 \% \mathrm{WF}$ and $80 \% \mathrm{WF}$ which had mean scores of 7.50 and 6.85 respectively, $10 \% \mathrm{SF}$ and $20 \% \mathrm{SF}, 40 \% \mathrm{SF}$ and $50 \% \mathrm{SF}$ were also not significantly different from each other. For overall acceptability, it ranged from 4.05 to 7.50 where the highest value was $100 \% \mathrm{WF}$ and the least was $50 \% \mathrm{WF}$. It was observed in each parameters that with the degree of incorporation of sesame flour, there was decrease in the mean score, except for sample with 80\%WF:20\%SF, which most times had higher score than all other samples that was substituted with roasted sesame flour, this might be the perfect blend to make spaghetti from wheat-sesame flour. According to Saklar $e t$ al.[42] roasting aims at the improvement of sensory properties through the change of colour, developing characteristic taste and flavour substances, as well as improving texture.

\section{Conclusion}

This study has revealed that the nutritional status of spaghetti can be enhanced by addition of roasted sesame flour. This can help in solving the lingering problem of protein malnutrition and also decreasing over reliance on wheat flour thus, reducing the cost of wheat flour. The spaghetti produced from wheat-sesame flour blends could be recommended for consumption at $20 \%$ inclusion level. Further work can be carried out on storage ability and moisture sorption isotherm of the flour blends.

\section{References}

[1] K. Vijayakumari, P. Siddhuraju, and Janardhanan, Effect of domestic processing on the levels of certain antinutrients in prosopischilensis (Molina) Stunz seeds, Food Chemistry, 59(3), 1997, 367-371.

[2] F.M. Makinde, and R. Akinoso, Comparison between the nutritional quality of flour obtained from raw, roasted and fermented sesame (Sesamum indicum L.) seed grown in Nigeria. Acta Sci. Pol., Technol. Aliment 13(3), 2014, 309-319

[3] E.M. Escamilla-Silva, S.H. Guzman-Maldonado, A. Cano-Medinal, G.A. Gonzalez-Alatorre, Simplified process for the production of sesame protein concentrate, Differential scanning colorimetry and nutritional, physicochemical and functional properties, Journal of the Science of Food and Agriculture, 83, 2003, 972-979.

[4] E.A. Weiss, Oil Seed Crop (2nd ed. Blackwell Science, Oxford, U.K. 2000) 131-164

[5] www.whfoods.com/genpage.php

[6] R.V. Cooney, L.J Custer, L. Okinaka, and A.A. Franke, Effects of dietary sesame seeds on plasma tocopherols levels, Nutrition and Cancer, 39, 2001, 66-71.

[7] M.A. Agiang, I.B. Umoh, A.I. Essien, and M.U. Eteng, Nutrient changes and antioxidant contents of Beniseed soup during cooking using a Nigerian Traditional method, Pakistan Journal of Biological Sciences, 13, 2010, 1011-1015. 
[8] L. Monge, G. Cortassa, F. Fiocchi, G. Mussino, Q. Carta, Glyco-insulinaemic response, digestion and intestinal absorption of the starch contained in two types of spaghetti, Diabetes, Nutrition and Metabolism, 3, 1990, 239-246.

[9] E.S.M. Abdel-Aal and P. Hucl, Amino acid composition and in vitro digestibility of selected ancient wheats and their end products, Journal of Food Composition and Analysis 15(6), 2002, 737-747.

[10] N. Sozer, Rheological properties of rice pasta dough supplemented with proteins and gums, Food Hydrocolloids, 23, 2009, 849855.

[11] L. Cleary, and C. Brennan, The influence of $\alpha(1 \rightarrow 3)(1 \rightarrow 4)-\beta$-D-glucan rich fraction from barley on the physico-chemical properties and in vitro reducing sugars release of durum wheat pasta, International Journal of Food Science and Technology, 41 , 2006, 910-918.

[12] J.E. Dexter, and R.R. Matsuo, The effect of gluten protein fractions on pasta dough and making quality, Cereal Chemistry, 55, 1978, 44-57.

[13] S.Y. Giami, T. Amasisi, and G. Ekiyor, Comparison of bread properties of composite flour from kernels of toasted and boiled African Bread fruit (Treculia africandecne) seeds, Journal of Raw materials, 1(1), 1992, 10-25.

[14] G.I. Onwuka, Food analysis and instrumentation theory and practice (Napthal prints, 2005) 133-134.

[15] A.A. Adebowale, M.T. Adegoke, S.S. Sanni, M.O. Adegunwa, and G.O. Fetuga, Functional properties and biscuit potentials of sorghum-wheat flour composite, American journal of food Technology, 7, 2009, 372-379.

[16] AOAC, Official Methods of Analysis of Chemistry (17th Edition Washington, D.C. Association of Official Analytical Chemists, 2000).

[17] F. Rampersad, S. Laloo, A. La-Borde, K. Maharaj, L. Sookhai, J. Teelucksingh, and S. Reid, Chemical quality of raw oysters in Trindad and the attributes, knowledge and perceptions of the public about its consumption, Epidemiological infection, 123, 2013, $241-250$

[18] G. Udo, and J.A. Ojuwole, Experimental procedure of analysis in the Laboratory (Oxford University Press, Ibadan, 1986).

[19] AOAC, Official Methods of Analysis of Chemistry (18th Edition Washington, D.C. Association of Official Analytical Chemists, 2010).

[20] J. Ochai, and A. Kolhatkan, (2000). Medical laboratory science and theory and practical (MC Grow Hill, New Delhi, India, 2000) 85-186.

[21] T.W. Fagbemi, and A.A.A. Oshodi, Chemical composition and functional properties of full-fat fluted pumpkin seed flour (Telfairia occidentalis), Nigerian food Journal, 9, 1990, 26-32.

[22] A.J. Ihekoronye, and P.O. Ngoddy, Integrated Food Science and Technology for the Tropics (Macmillan Publs. Ltd. 1985)

[23] A.A. Oladunmoye, R. Akinoso, and A.A. Olapade, Evaluation of some physical-chemical properties of wheat, cassava, maize and cowpea flours for bead making, Journal of food quality, 33, 2010, 693-708. DOI: 10-1111/j.1746-4557.2010.00351.x

[24] B.I. Offia-Olua, Chemical, functional and pasting properties of wheat (Triticum spp)-Walnut (Juglans regia) Flour, Food and Nutrition Sciences, 5, 2014, 1591-1604.

[25] M.I. Gurr, and N.G. Asp, Dietary Fiber, ILSI Europe Concise Monograph Series. (Brussels, Belgium: ILSI Press, 1994) 15-19.

[26] A. Aleixandre, and M. Miguel, Dietary fiber in the prevention and treatment of metabolic syndrome: a review, Critical Reviews in Food Science and Nutrition 48, 2008, 905-912.

[27] O.F. Osundahunsi, T.N. Fagbemi, E. Kesselman, and E. Shimoni, Composition of the physiochemical properties and pasting characteristics of flour and starch from red and white sweet potato cultivars. Journal of Agricultural and Food Chemistry, 51, 2003, 2232-2236.

[28] A.A. Yusuff, H. Ayedun, and L.O. Sanni, Chemical composition and functional properties of raw and roasted Nigerian benniseed (Sesamum indicum) and Bambara groundnut (Vigna subterranean), Food Chemistry 111, 2008, 227-282.

[29] D. Karuna, G. Noel, and K. Dilip, Production and use of raw potato flour in mauritan traditional foods. Food and nutrition bulletin, 17(2), 1996, United Nation University.

[30] F.M.A. Abass, R. Saifullah, and M.E. Azhar, Assessment of physical properties of ripe banana flour prepared from two varieties: cavedish and dream bananas, International Food Research Journal, 16, 2009, 183-189.

[31] I.A. Onimawo, and K.M. Egbekun, Comprehensive food science and nutrition (Revised Edition, Ambik Publishers, Benin City, 1998).

[32] S.N. Moorthy, and T. Ramanujam, Variation in properties of starch in cassava varieties in relation to age of the crop starch, Starke, 38, 1986, 58-61.

[33] B. Daramola, and S.A. Osanyinlusi, Investigation on modification of cassava starch using active components of ginger roots (Zingiber officinale Roscoe) African Journal of Biotechnology, 5(10), 2006, 917-920.

[34] H.N. Dengate, H.N. (1984). Swelling, pasting and gelling of wheat starch, in Pomeranz, (Ed.), Advances in cereal science and technology, American association for clinical chemistry (AAAC), (Washington DC, 1984).

[35] H.N. Ayo-Omogie, and R. Ogunsakin, Assessment of chemical, rheological and sensory properties of fermented maize-cardaba banana complementary Food. Food and Nutrition Sciences, 4, 2013, 844-850.

[36] R. Singh, G. Singh, and G.S. Chauhan, Effect of incorporation of defatted soy flour on the quality of biscuits, Journal of Food Science and Technology, 33, 2005, 355-7.

[37] O. Omueti, B. Otegbayo, O. Jaiyeola, and O. Afolabi, (2009). Functional properties of complementary diets developed from Soybean (Glycine max), Groundnut (Arachis hypogea) and Crayfish (Macro brachium spp.), Journal of Environmental Agricultural and Food Chemistry 8(8), 2009, 563-573.

[38] I.E. Mbaeyi, and J.C. Onweluzo, Functional properties of sorghum (Sorghum bicolor) pigeon pea (Cajanus cajan) flour blends and storage stability of a flaked breakfast formulated blends. Pakistan Journal of Nutrition 12(4), 2013, 382-397.

[39] C.M. Weaver, and R.P. Heaney, Calcium in Human Health (Humana Press Inc. Totowa New Jersey, 2006). http://dx.doi.org/10.1007/978-1-59259-961-5.

[40] The Food and Nutrition Board, (Oxford University, United State of America, 1980)

[41] C.A. Ikpeme-Emmanuel, N.C. Osuchukwu, and L. Oshiele, Functional and sensory properties of wheat (Aestium triticuim) and taro flour (ColocasiIa esulanta) composite bread. African Journal of Food Science 4(5), 2010, 248-253.

[42] S. Saklar, S. Katnas, and S. Ungan, Determination of optimum hazelnut roasting conditions, International Journal of Food Science and Technology 36, 2001, 271-281 